Review / Artículo de revisión / Revisão - Tipo 3

\title{
MANET: Advantages, challenges and applications for education
}

\author{
María Alejandra Bernal / mabernall@correo.udistrital.edu.co \\ Wilfer Sneyder Cortés / wscortesu@correo.udistrital.edu.co \\ Miguel Ángel Leguizamón / maleguizamonp@correo.udistrital.edu.co \\ Universidad Distrital Francisco José de Caldas, Bogotá-Colombia
}

ABSTRACT Presently, telecommunications are key for several human activities. However, there are some places where their use is not possible because of the absence of the required infrastructure: antennas, routers and switches. The Mobile Ad-Hoc Networks [MANET] has become a key tool for wireless networks because of its two major advantages: they do not depending on infrastructure and offers complete mobility. This paper aims to show their development; introduce their basic concepts, features, advantages, challenges and operation modes; and present how it can be useful, emphasizing in day to day activities, as education.

KEYWORDS MANET; ad-hoc networks; routing protocols; e-learning.

MANET: ventajas, retos y aplicaciones para la educación

RESUMEN En la actualidad, las telecomunicaciones son fundamentales para el desarrollo de las actividades en las que se desenvuelve el hombre. Sin embargo, hay ocasiones en que ellas son imposibles debido a la ausencia de infraestructura - antenas, routers y switches-. Las Mobile Ad-Hoc Networks [MANET]) son una tecnología que ha adquirido importancia en el campo de las redes inalámbricas gracias a que no dependen de infraestructura y ofrecen una total libertad de movilidad. Este artículo tiene como fin evidenciar su desarrollo; introducir conceptos básicos de ellas, sus características, ventajas, retos y modos de operación; y mostrar su utilidad práctica, con énfasis en actividades cotidianas, como la educación.

PALABRAS CLAVE MANET; redes ad-hoc; protocolos de enrutamiento; educación virtual.
MANET: vantagens, desafios e aplicações para a educação

RESUMO Atualmente, as telecomunicações são essenciais para o desenvolvimento das atividades nas quais o homem participa. No entanto, há momentos em que elas são impossíveis devido à ausência de infra-estrutura - antenas, roteadores e switches -. As Mobile Ad-Hoc Networks [MANET] são uma tecnologia que se tornou importante no campo das redes sem fio porque não dependem da infra-estrutura e fornecem total liberdade de mobilidade. Este artigo pretende demonstrar seu desenvolvimento; introduzir conceitos básicos sobre elas, suas características, vantagens, desafios e modos de operação; e mostrar sua utilidade prática, com ênfase nas atividades diárias, como a educação.

PALAVRAS-CHAVE MANET; redes ad hoc; protocolos de roteamento; educação virtual 


\section{Introduction}

The wireless mobile networks arise in 1980, from the beginning they have been characterized by the free mobility that the user possesses in a determined radius. It is until the beginning of the 21 st century when it is possible to demonstrate the undeniable widespread growth of the mobile device in society in terms of quality and quantity, its uses vary and include communicative and work purposes, and leisure; the main activities include access to social networks and Web content consultation (Nielsen, 2014).

Wireless networks have been classified into two categories, according to their infrastructure (Helen \& Arivazhagan, 2014). In the first, all the nodes are connected to one or more devices known as Access Point [AP], which manage the connectivity between the wireless nodes and usually delegate the routing tasks to the traditional devices provided for that purpose, to those who are connected, at some point of the network; although the network is wireless, it is linked to the position of the AP and the wavelength of the device, which determines the coverage and scope of a network, limiting the mobility of the user to a geographically determined radius. The second architecture, for its part, does not require intermediary devices such as $\mathrm{APS}_{\mathrm{s}}$, nor layer 2 and 3 devices for routing processing, failure control and sending of information, that is, does not require any physical representation of network infrastructure for its operation (Frodigh, Johansson, \& Larsson, 2000); terminals are the only actor involved and its distribution, of dynamic nature and multi-hop, forms an Ad Hoc network (Stojmenovic \& Lin, 2001); in the absence of a centralized architecture, the nodes act as a router and are able to receive and send data in a collaborative network that can be shaped and moved to where the user wants while retaining the same robustness and complexity of a conventional network.

It is proposed to demonstrate the applicability that the Mobile Ad hoc Network [MANET] can have in such common and popular fields as education, taking advantage, on the one hand, of the availability of mobile devices, both in the student body and in the teaching staff, and on the other hand, the possibility of creating academic data networks in areas that do not have pre-established infrastructure, mobile network coverage or Internet access, generating the creation of collaborative circles for teaching and a system to transmit information among students and teachers. Likewise, the concepts collected and analyzed related to the MANET will be announced.

\section{Introducción}

Las redes móviles inalámbricas surgen en 1980, desde un principio se han caracterizado por la libre movilidad que posee el usuario en un radio determinado. Es hasta el inicio del siglo XXI cuando se logra evidenciar la innegable masificación del dispositivo móvil en la sociedad en términos de calidad y cantidad, sus usos varían e incluyen fines comunicativos y laborales, y ocio; se destacan, como principales actividades el acceso a redes sociales y la consulta de contenido Web (Nielsen, 2014).

Las redes inalámbricas se han clasificado en dos categorías, de acuerdo con su infraestructura (Helen \& Arivazhagan, 2014). En la primera, todos los nodos se encuentran conectados a uno o más dispositivos conocidos como Access Point $[\mathrm{AP}]$, que administran la conectividad entre los nodos inalámbricos y suelen delegar las tareas de switcheo y ruteo a los tradicionales dispositivos dispuestos para tal fin, a quienes se encuentran conectados, en algún punto de la red; aunque la red es inalámbrica, se encuentra ligada a la posición del AP y a la longitud de onda del dispositivo, lo que determina la cobertura y el alcance de una red, limitando la movilidad del usuario a un radio geográficamente determinado. La segunda arquitectura, por su parte, no requiere de dispositivos intermediarios como los AP, ni de dispositivos de capas 2 y 3 para el procesamiento del enrutamiento, control de fallos y envío de información, es decir, no requiere de alguna representación física de infraestructura de red para su operación (Frodigh, Johansson, \& Larsson, 2000); los terminales son el único actor involucrado y su distribución, de naturaleza dinámica y multisalto, conforma una red Ad Hoc (Stojmenovic \& Lin, 2001); al no existir una arquitectura centralizada, los nodos actúan como router y son capaces de recibir y enviar datos en una red colaborativa que puede ser conformada y trasladada hacia donde el usuario desee, conservando la misma robustez, y complejidad de una red convencional.

Se propone demostrar la aplicabilidad que pueden poseer las Mobile Ad hoc Network [MANET] en ámbitos tan comunes y populares como la educación, aprovechando, por una parte la disponibilidad de dispositivos móviles, tanto en el estudiantado, como en el cuerpo docente, y por otra, la posibilidad de crear redes de datos académicas en áreas que no cuentan con infraestructura preestablecida, cobertura de redes móviles o acceso a Internet, generando la creación de círculos colaborativos para la enseñanza y un sistema para lograr transmitir información entre estudiantes y docentes. Asimismo, se darán a conocer los conceptos recopilados y analizados relativos a las MANET.

La metodología para definir las fuentes se basó en identificar que proviniesen de lugares reconocidos, para así asegurar la calidad y veracidad de la información consultada. Libros, artículos publicados en revistas científicas o en publicaciones resultantes de congresos en computación, documentos de la IETF, consultas en bases de datos académicas como la IEEE y el motor de búsqueda de Google 
Academics, teniendo en cuenta los sitios que más han sido referenciados, son ejemplos de las fuentes consultadas y seleccionadas.

Lo que sigue del presente artículo se divide en cuatro secciones conformadas de la siguiente manera: en la primera se define el concepto de MANET, junto con las ventajas y retos asociados, también se nombra la clasificación de los algoritmos de enrutamiento; la segunda contiene la clasificación y definición de los protocolos asociados a las redes MANET, tales como los algoritmos proactivos, reactivos e híbridos; en la tercera se dan a conocer las aplicaciones de este tipo de redes, haciendo énfasis en la educación; para finalizar, se concluye el trabajo evidenciando la utilidad de aplicaciones orientadas al campo de la educación que hagan uso de tecnologías móviles con infraestructuras dinámicas en redes de tipo Ad-hoc.

\section{Mobile Ad-Hoc networks: definición y modo de operación}

El concepto de MANET se refiere a redes inalámbricas de datos que funcionan a partir del trabajo colaborativo de los nodos involucrados que, en este caso, son exclusivamente dispositivos móviles como smartphones, smartwatch y tablets, con antenas que poseen coberturas limitadas y soportan tecnologías como WiFi 802.11, Bluetooth (Parker, 2011), ZigBee (ZigBee Alliance, 2016), 6LoWPAN (Shelby \& Awasthi, 2013).

Las principales características de los dispositivos móviles son: autonomía, movilidad y masificación en la sociedad moderna, características que amplían los campos de acción de las MANET, como redes que no requieren de infraestructura fija ni del establecimiento de topologías estáticas ni de dispositivos administradores-enrutadores -switches, routers o access point-, porque son los nodos participantes quienes cumplen con los papeles de emisor, receptor, dispositivo intermediario y enrutador, según sea el caso.

El modo de operación de las MANET hace uso de la tradicional estructura TCP/IP para proveer la transmisión peer to peer dentro de un gran entorno multipunto (Singh \& Awasthi, 2013)

La transmisión de datos de un punto a otro en las MANET se basa en el establecimiento de adyacencias con mensajes de inundación a los vecinos dentro de la zona de cobertura del nodo origen (Rocabado, Arias, Díaz \& Moreno, 2013); si el nodo destino no se encuentra dentro de la cobertura del origen, los nodos vecinos realizarán la inundación dentro de su área de cobertura, proceso que se repetirá iterativamente, hasta localizar al nodo destino, como se ilustra en la Figura 1.

Ya que el modo de operación, los canales de transmisión y la administración del tráfico en éste tipo de redes difiere de los métodos convencionales, se hace necesaria la aplicación y ejecución de protocolos especializados para MANET.
The methodology to define the sources was based on identifying that they came from recognized places, in order to assure the quality and veracity of the information consulted. Books, articles published in scientific journals or publications resulting from computer conferences, IETF documents, queries in academic databases such as the IEEE and the Google Academics search engine, taking into account the most referenced sites, they are examples of the sources consulted and selected.

What follows from the present article is divided into four sections conformed in the following way: in the first, the concept of MANET is defined along with the associated advantages and challenges, the classification of the routing algorithms is also named; the second includes the classification and definition of the protocols associated with MANET networks, such as proactive, reactive and hybrid algorithms; in the third, the applications of this type of networks are made known, with an emphasis on education; finally, the work is concluded by demonstrating the usefulness of applications oriented to the field of education that make use of mobile technologies with dynamic infrastructures in Ad-hoc networks.

\section{Mobile Ad-Hoc networks: Defini- tions and operation mode}

The concept of MANET refers to wireless data networks that operate from the collaborative work of the nodes involved, which in this case are exclusively mobile devices such as smartphones, smartwatch and tablets, with antennas that have limited coverage and support technologies such as WiFi 802.11, Bluetooth (Parker, 2011), ZigBee (ZigBee Alliance, 2016), 6LoWPAN (Shelby \& Awasthi, 2013).

The main characteristics of mobile devices are autonomy, mobility and widespread growth in modern society, characteristics that broaden the fields of action of the MANET, such as networks that do not require a fixed infrastructure or the establishment of static topologies or administrator-router devices -switches, routers or access point-, because the participating nodes are those who fulfill the roles of sender, receiver, intermediary device and router, as the case may be.

The MANET mode of operation makes use of the traditional TCP/IP structure to provide peer-to-peer transmission within a large multipoint environment (Singh \& Awasthi, 2013).

The transmission of data from one point to another in the MANET is based on the establishment of adjacencies with inundation messages to the neighbors within the coverage area of the origin node (Rocabado, Arias, Díaz \& Moreno, 
2013); if the destination node is not within the coverage of the origin, the neighboring nodes will flood within its coverage area, a process that will be repeated iteratively, until the destination node is located, as illustrated in FIGURE 1.

Since the mode of operation, transmission channels and traffic management in this type of networks differs from conventional methods, it is necessary to apply and execute specialized protocols for MANET.

Its advantages are:

- Flexibility: they can be installed easily and dynamically in any place and situation, depending on the need (González, 2012), thus providing a great advantage over other types of networks that need an infrastructure for their correct operation.

- Movement of the nodes: for various situations in which this type of network can be installed, it is very useful that the nodes have a free movement within the coverage (Aguilera, 2013), since it allows the user to perform other tasks and stay connected.

- Decentralization: the devices within the network are autonomous nodes, which allows anyone to play the role of a router and not require a single device to route the messages (Latiff \& Fisal, 2003), causing that the fall of any link does not affect the establishment of the communication.

- Scalability: the addition of new nodes to the network does not represent a challenge for this type of networ$\mathrm{ks}$, due to the nature of the devices that are in constant movement (Alonso \& Rivera, 2007).

- Economy: its installation cost is low because it does not depend on traffic administrators, such as switches and routers (Yadav, \& Uparosiya, 2014). In addition, it does not need wiring nor a centralized administration.

- Multi-hop: the nodes have low power antennas and this makes their range of coverage scarce, but thanks to the multi-hop characteristic of the MANETs the nodes send recognition messages to their adjacent nodes until one of them has as a neighbor the target device and thus achieve communication (Rocabado et al., 2013).

- Autonomous formation: the nodes that integrate the network take a peer-to-peer [P2P] position (García, 2009), thus forming their own dynamic topology when entering the MANET; likewise, the devices do not require human interventionsince they are able to associate to establish a communication, as long as they are within the coverage area (Bertolín, 2012).

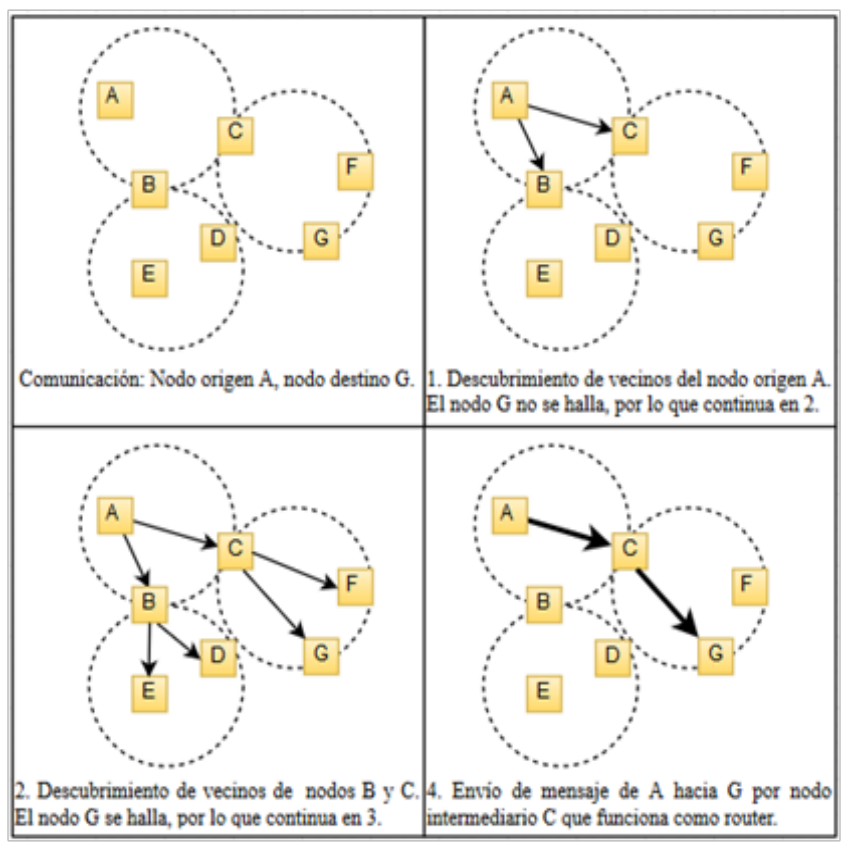

Figure 1. Messages transmitting in MANET / Transmisión de mensajes en MANET

Sus ventajas son:

- Flexibilidad: se logran instalar fácilmente y de forma dinámica en cualquier lugar y situación, dependiendo de la necesidad (González, 2012), proporcionando así una gran ventaja frente a otros tipos de redes que necesitan una infraestructura para su correcta operación.

- Movimiento de los nodos: para diversas situaciones en las cuales este tipo de red puede ser instalada, es de gran utilidad que sus nodos tengan un libre movimiento dentro de la cobertura (Aguilera, 2013), ya que posibilita al usuario realizar otras tareas y mantenerse comunicado.

- Descentralización: los dispositivos dentro de la red son nodos autónomos, lo que permite que cualquiera logre hacer el papel de router y no se requiera entonces de un único dispositivo que encamine los mensajes (Latiff \& Fisal, 2003), lo que conlleva a que la caída de algún enlace no afecte el establecimiento de la comunicación.

- Escalabilidad: la adición de nuevos nodos a la red no representa un reto para este tipo de redes, debido a la naturaleza de los dispositivos que están en constante movimiento (Alonso \& Rivera, 2007).

- Economía: su costo de instalación es bajo porque no depende de dispositivos administradores de tráfico, como switches y routers (Yadav, \& Uparosiya, 2014). Además, no necesita de cableado, ni una administración centralizada.

- Multi-salto: los nodos poseen antenas con poca potencia y esto hace que su rango de cobertura sea escaso, pero gracias a la característica multi-salto de las MANET los nodos envían mensajes de reconoci- 
miento a sus nodos adyacentes hasta que alguno de ellos tenga como vecino al dispositivo objetivo y así lograr la comunicación (Rocabado et al., 2013).

- Formación autónoma: los nodos que integran la red toman una posición peer-to-peer [P2P] (García, 2009), conformando de este modo su propia topología dinámica al entrar a la MANET; asimismo, los dispositivos no requieren de intervención humana, ya que son capaces de asociarse para establecer una comunicación, siempre y cuando estén dentro del área de cobertura (Bertolín, 2012).

- Organización autónoma: en una red con topología tan dinámica, es posible la re-organización de los nodos y que el funcionamiento de los dispositivos no se vea afectado por la entrada o salida de terminales en la red (Bertolín, 2012).

Los retos que enfrenta el desarrollo de este tipo de redes son:

- Energía: los nodos de las MANETS están constituidos por dispositivos con baterías -las cuales tienen un tiempo de vida reducido- lo que provoca, con el transcurrir del tiempo, nodos y enlaces caídos (Frodigh et al., 2000) y limitantes en el mantenimiento y la vida de la MANET.

- Nuevos protocolos: al poseer las MANET una topología dinámica, es necesaria crear protocolos que soporten dicha característica, su objetivo debe enfocarse en descubrir y mantener las rutas y, además, en eliminar las que ya no son usadas; asimismo, deben ser protocolos optimizados que no posean elevados niveles de consumo de CPU y, por ende, que no afecten la batería de los nodos (González, 2012; Frodigh et al., 2000).

- Enlaces rotos: debido al constante movimiento aleatorio que tienen los nodos dentro de la red es factible que los mismos estén entrando y saliendo de la cobertura de la MANET, haciendo que las rutas ya establecidas para la comunicación deban ser recalculadas o lleguen a fallar (Aguilera, 2013).

- Ancho de banda y medio de transmisión: al usar enlaces inalámbricos, la red posee un ancho de banda reducido. Además, el aire, que es el medio de propagación, puede verse afectado por interferencia y ruido (Rodríguez, 2005).

- Seguridad: al ser el aire el medio compartido de las MANET, la comunicación puede ser fácilmente interferida, así cualquiera que tenga acceso a la red, podrá capturar los mensajes que circulan en ella, más aún si no se han establecido criterios de autenticación, confidencialidad y no repudio (Rocabado et al., 2013).

- Procesamiento limitado: que los nodos sean pequeños, con poca capacidad de CPU, limita la realización de operaciones criptográficas que eleven la
- Autonomous organization: in a network with such a dynamic topology, the re-organization of the nodes is possible and the functioning of the devices is not affected by the entry or exit of terminals in the network (Bertolín, 2012).

The challenges that face the development of this type of networks are:

- Energy: the nodes of the MANETs are constituted by devices with batteries - which have a reduced life timewhich causes, with the passing of time, fallen nodes and links (Frodigh et al., 2000) and limitations in the maintenance and life of the MANET.

- New protocols: since the MANETs possess a dynamic topology, it is necessary to create protocols that support this characteristic, their objective must focus on discovering and maintaining the routes and, in addition, on eliminating those that are no longer used; likewise, they must be optimized protocols that do not have high levels of CPU consumption and, therefore, that do not affect the battery of the nodes (González, 2012; Frodigh et al., 2000).

- Broken links: due to the constant random movement of the nodes within the network, it is feasible that they are entering and leaving MANET coverage, making the already established routes for communication to be recalculated or fail (Aguilera, 2013).

- Bandwidth and transmission medium: when using wireless links, the network has a reduced bandwidth. In addition, air, which is the means of propagation, can be affected by interference and noise (Rodríguez, 2005).

- Security: since air is the shared medium of MANETs, communication can easily be interfered, so anyone who has access to the network will be able to capture the messages circulating in it, especially if criteria for authentication, confidentiality and non-repudiation have not been established (Rocabado et al., 2013).

- Limited processing: small nodes, with little CPU capacity, limits the performance of cryptographic operations that increase security; also, the low processing of the terminals affects the performance of the MANET unless the correct protocols for the establishment of routes are applied (Rocabado et al., 2013). On the other hand, its low processing capacity does not support the traditional procedures for route discovery and calculation of metrics that a layer 3 device possesses. 
The classification of the way in which the algorithms designed for the administration and routing of traffic of a network operate are divided into three categories -Link State, Distance-Vector and Source Routing- which are specified below, in additiondevices will be denoted as nodes with routing processing capability, that is, routers and switches for conventional networks and mobile devices for MANET networks.

\section{Link state}

The protocols that work under this algorithm are characterized by frequently consulting the state of the links that connect a node with its neighbors and by assigning a numerical value to the links according to conditions established by the protocol. The information collected is distributed throughout the network at established time intervals or when relevant events occur - such as the drop of links or the addition of new nodes-, reaching the total convergence of the network, since all the nodes build the topology as a map or graph and have knowledge of it (Frikha, 2011).

The advantage of this type of operation is that, in addition to being able to calculate multiple routes to the same destination, when one route fails the other participating nodes have the criterion of selecting the new alternate road, even if they are not involved in the route, since they know the topology in its entirety. The most relevant traditional routing protocol that makes use of the Link State algorithm is OSPF [Open Shortest Path First] (Bokotey, Mason, \& Morrow, 2003) based on Dijkstra, which in addition to finding alternate routes, offers load balancing, which increases the resilience. Normally the protocols of the Link State are more stable and robust, but much more complex than those based on the Distance-Vector algorithm.

\section{Distance-Vector}

This algorithm is less complex than the Link State algorithm, each node of the network transmits, via unicast or multicast, a vector with the costs towards the known achievable destinations; then, each neighbor analyzes in its entirety the routing table received in search of new routes or changes in the topology; when it finishes analyzing, it discards the redundant information and stores the new one in its own routing table, saving only fragments of the topology and not the entire network distribution.

Although the protocols based on Distance-Vector are simpler and cheaper to implement, they have drawbacks regarding their performance, because even if the topology has not changed over a long period of time, updates are still sent periodically and the neighbors will have to analyze, in all the seguridad; además, el bajo procesamiento de los terminales afecta el desempeño de la MANET a menos que se apliquen los protocolos correctos para el establecimiento de rutas (Rocabado et al., 2013). Por otro lado, su baja capacidad de procesamiento no soporta los procedimientos tradicionales para el descubrimiento de rutas y el cálculo de métricas que un dispositivo de capa 3 posee.

La clasificación del modo en que operan los algoritmos diseñados para la administración y el ruteo de tráfico de una red, están divididas en tres categorías -Estado de Enlace, Vector-Distancia y Source Routing- que se especifican a continuación, donde además se denotará como nodos a los dispositivos con capacidad de procesamiento de ruteo, es decir, routers y switches para redes convencionales y dispositivos móviles para redes MANET.

\section{Estado del enlace}

Los protocolos que trabajan bajo este algoritmo se caracterizan por consultar frecuentemente el estado de los enlaces que conectan a un nodo con sus vecinos y por asignar un valor numérico a los enlaces según condiciones establecidas por el protocolo. La información recopilada se distribuye por toda la red en intervalos de tiempo establecidos o cuando se presentan eventos relevantes - como la caída de enlaces o la adición de nuevos nodos-, alcanzando la convergencia total de la red, puesto que todos los nodos construyen la topología como mapa o grafo y tienen conocimiento de ella (Frikha, 2011).

La ventaja de éste tipo de operación es que, además de poder calcular múltiples rutas a un mismo destino, cuando una ruta falla los demás nodos participantes tienen el criterio de seleccionar el nuevo camino alterno, así no estén implicados en la ruta, puesto que conocen la topología en su totalidad. El protocolo de enrutamiento tradicional más relevante que hace uso del algoritmo de Estado de Enlace es OSPF [Open Shortest Path First] (Bokotey, Mason, \& Morrow, 2003) basado en Dijkstra, que además de hallar rutas alternas, ofrece balanceo de cargas, lo que incrementa la resiliencia. Normalmente los protocolos del Estado de Enlace son más estables y robustos, pero mucho más complejos que los basados en el algoritmo Vector-Distancia.

\section{Vector-Distancia}

Este algoritmo es menos complejo que el algoritmo de Estado de Enlace, cada nodo de la red transmite, vía unicast o multicast, un vector con los costos hacia los destinos alcanzables conocidos; luego, cada vecino analiza en su totalidad la tabla de enrutamiento recibida en búsqueda de nuevas rutas o cambios en la topología; cuando termina de analizar, desecha la información redundante y almacena la nueva en su propia tabla de enrutamiento, guardando sólo fragmentos de la topología y no toda la distribución de red.

Aunque los protocolos basados en Vector-Distancia resultan más sencillos y económicos de implementar, poseen inconvenientes respecto de su desempeño, porque aún si la topología no ha presentado cambios en un largo lapso de 
tiempo, las actualizaciones se siguen enviando de manera periódica y los vecinos tendrán que analizar, en todas las ocasiones, la tabla recibida, lo que genera un consumo innecesario de CPU y ancho de banda en la red; además, en caso de caída de un enlace, los nodos no lo notarán hasta que se cumpla el tiempo de actualización, lo que conlleva a un periodo en donde varios paquetes pueden perderse $y$, por ello, no llegar a su destino.

Por lo anterior, los protocolos bajo la clasificación Vector-Distancia tienen una convergencia más lenta y son propensos a la generación de ciclos y contadores infinitos (Chang, Gaydadjiev \& Vassiliadis, 2005) que aíslan a nodos funcionales, ralentizan la red y abren la puerta a posibles intrusiones indeseadas.

\section{Fuente de enrutamiento}

Los protocolos que se rigen bajo la política de Source Routing se caracterizan porque las decisiones relacionadas con el enrutamiento de los paquetes son tomadas por la fuente del paquete, es decir, el origen determina la cantidad de saltos y los nodos intermedios que atravesará antes de llegar a su destino (Rey, Quiñones, \& García, 2014a; 2014b).

En los algoritmos Vector-Distancia y Estado de Enlace, cada dispositivo por el que pasa el mensaje lee la dirección destino y toma decisiones respecto de su tabla de enrutamiento para determinar el siguiente salto o dar por terminada la transmisión; en cambio, en las transmisiones basadas en Source Routing (2013), el nodo origen es quien determina toda o parte de la ruta hacia el destino, lo que reduce, en gran medida, el consumo de CPU de los siguientes saltos, y el ancho de banda, porque ahora, los nodos intermediarios sólo leerán la ruta establecida y se limitarán a enviar el paquete al siguiente salto dentro de la ruta.

Los inconvenientes que se presentan al implementar estos algoritmos surgen cuando las redes son extensas y las rutas incluyen una gran cantidad de saltos, pues cada ruta debe ser incluida en la cabecera del paquete, lo que, por ende, las sobrecarga (Kumar, Selvarani \& Kumar, 2013) y reduce el desempeño general de la red.

\section{Mobile Ad-Hoc networks: protocolos de enrutamiento}

Los protocoles se clasifican según el modo en el que los nodos mantienen y almacenan la información de ruteo en: proactivos, reactivos e híbridos, a continuación se describe cada uno de ellos.

\section{Proactivo}

Éste tipo de protocolo basa su funcionamiento, principalmente, en la transmisión periódica de paquetes de control a todos los demás nodos para descubrir rutas, cambios en la red y obtener una topología consistente y actualizada (López, Barceló, \& García-Vidal, 2005). Si un nodo requiere de alguna ruta, la obtendrá inmediatamente, cuando se generan cambios en la topología se activan mensajes occasions, the received table, what generates an unnecessary consumption of CPU and bandwidth in the network; in addition, in case of a fall of a link, the nodes will not notice it until the update time is accomplished, which leads to a period where several packets can be lost and, therefore, not reach their destination.

Due to the above, the protocols under the Distance-Vector classification have a slower convergence and are prone to the generation of infinite cycles and meters (Chang, Gaydadjiev \& Vassiliadis, 2005) that isolate functional nodes, slow down the network and open the door to possible unwanted intrusions.

\section{Source routing}

The protocols that are governed by the Source Routing policy are characterized because the decisions related to the routing of the packets are taken by the source of the packet, that is, the origin determines the number of hops and the intermediate nodes that it will cross before arriving at its destination (Rey, Quiñones, \& García, 2014a, 2014b).

In the Distance-Vector and Link State algorithms, each device through which the message passes reads the destination address and makes decisions regarding its routing table to determine the next hop or terminate the transmission; however, in the transmissions based on Source Routing (2013), the originating node is the one that determines all or part of the route to the destination, which reduces, to a large extent, the CPU consumption of the following hops, and the bandwidth, because now, the intermediate nodes will only read the established route and will only send the packet to the next hop within the route.

The disadvantages that arise when implementing these algorithms emerge when the networks are extensive and the routes include a large number of hops, since each route must be included in the header of the package, which, therefore, overloads them (Kumar, Selvarani \& Kumar, 2013) and reduces the overall performance of the network.

\section{Mobile Ad-Hoc netwprks: Routing protocols}

The protocols are classified according to the way in which the nodes maintain and store the routing information in proactive, reactive and hybrid, then each of them is described.

\section{Proactive}

This type of protocol bases its operation, mainly, on the periodic transmission of control packets to the others nodes to discover routes, changes in the network and obtain a consis- 
tent and updated topology (López, Barceló, \& García, 2005). If a node requires some route, it will obtain it immediately, when changes are generated in the topology, update messages are activated from the source node to all its neighbors.

Proactive protocols have the advantage of not generating any additional load for the creation of routes, because their fixed load, generated by the transmission of control packets, includes the cost of creating the route (Díaz, Marrone, Barbieri \& Robles, 2010), also they have very few delays since even if they are inactive, routes to all nodes are kept in the routing table, available to be consulted when required. On the other hand, this type of protocols becomes less effective in large networks, since when generating a greater amount of traffic to keep the tables updated in all the nodes, scalability and performance problems usually arise (Rey et al., 2014a; 2014b).

There are several proactive protocols that can be used in MANET, among which are Destination Sequence Distance Vector [DSDV] (Perkins \& Bhagwat, 1994); Optimized Link State Routing [OLSR] (Clausen \& Jacquet, 2003; Jacquet, Muhlethaler, Clausen, Laouiti, Qayyum \& Viennot, 2001); Better Approach to Mobile Ad hoc Networking [BATMAN] (Neumann, Aichele, Lindner \& Wunderlich, 2008); and Distance Routing Effect Algorithm for Mobility [DREAM] (Basagni, Chlamtac, Syrotiuk, \& Woodward, 1998).

\section{Reactive}

As established by Murazzo, Rodríguez and Martínez (2008) and Echaiz, Davicino and Ardenghi (2012) the reactive protocols work on demand, that is, only when a source node wishes to send data to a destination node, begins the discovery and establishment process of the route, procedure that makes use of the technique of flooding (Cho, 2005).

Routing on demand has advantages such as that it requires less overhead than proactive routing and makes better use of bandwidth (Lara, Olmedo, \& Rodríguez, s.f), which decreases network overload, since it does not make constant updates to its routes; its disadvantage is that the establishment of the communication is delayed because the new routes are not available to be used until the flood process is done and there is a way to reach the destination node (Ishibashi \& Boutaba, 2005).

Examples of the reactive protocols are: Ad Hoc On-Demand Distance Vector [AODV] (Perkins, Belding-Royer, \&Das, 2003a; 2003b); Dynamic Source Routing [DSR] (Johnson \& Maltz, 2007); Temporally Ordered Routing Algorithm [TORA] (Park \& Corson, 2001; Gupta, Sadawarti, \& Ver- de actualización desde el nodo origen a todos sus vecinos.

Los protocolos proactivos poseen la ventaja de no generar ninguna carga adicional para la creación de rutas, porque su carga fija, generada por la transmisión de los paquetes de control, incluye el coste de la creación de la ruta (Díaz, Marrone, Barbieri \& Robles, 2010), además poseen muy pocos retardos ya que aún si están inactivas, las rutas hacia todos los nodos se mantienen en la tabla de enrutamiento, disponibles para ser consultadas cuando se requiera. Por otra parte, este tipo de protocolos se hace menos efectivo en redes grandes, ya que al generar una mayor cantidad de tráfico para mantener las tablas actualizadas en todos los nodos, por lo general se presentan problemas de escalabilidad y rendimiento (Rey et al., 2014a; 2014b).

Existen varios protocolos proactivos que pueden emplearse en MANET, entre los cuales se encuentran Destination Sequence Distance Vector [DSDV] (Perkins \& Bhagwat, 1994); Optimized Link State Routing [OLSR] (Clausen \& Jacquet, 2003; Jacquet, Muhlethaler, Clausen, Laouiti, Qayyum \& Viennot, 2001); Better Approach to Mobile Ad hoc Networking [BATMAN] (Neumann, Aichele, Lindner \& Wunderlich, 2008); y Distance Routing Effect Algorithm for Mobility [DREAM] (Basagni, Chlamtac, Syrotiuk, \& Woodward, 1998).

\section{Reactivo}

Como establecen Murazzo, Rodríguez y Martínez (2008) y Echaiz, Davicino y Ardenghi (2012) los protocolos reactivos trabajan bajo demanda, es decir que, solo cuando un nodo origen desea enviar datos a un nodo destino, empieza el proceso de descubrimiento y establecimiento de ruta, procedimiento que hace uso de la técnica de inundación flooding (Cho, 2005).

El ruteo por demanda posee ventajas como que requiere menos overhead que el ruteo proactivo y hace mejor uso del ancho de banda (Lara, Olmedo, \& Rodríguez, s.f), lo que disminuye la sobrecarga de la red, ya que no hace constantes actualizaciones en sus rutas; su desventaja radica en que el establecimiento de la comunicación es más tardío porque las nuevas rutas no están disponibles para ser usadas sino hasta que se hace el proceso de inundación y se encuentra la forma de llegar al nodo destino (Ishibashi \& Boutaba, 2005).

Ejemplos de los protocolos reactivos son: Ad Hoc On-Demand Distance Vector [AODV] (Perkins, Belding-Royer, \& Das, 2003a; 2003b); Dynamic Source Routing [DSR] (Johnson \& Maltz, 2007); Temporally Ordered Routing Algorithm [TORA] (Park \& Corson, 2001; Gupta, Sadawarti, \& Verma, 2010); Location Aided Routing [LAR] (Ko \& Vaidya, 2000); y Link Quality Source Routing [LQSR] (Draves, Zill \& Padhey, 2008).

\section{Hibrido}

Es una combinación de los protocolos de ruteo reactivo y proactivo, fue propuesto con la finalidad de reducir las sobrecargas de los protocolos proactivos asociados a la 
constante transmisión de mensajes de control para la actualización de rutas (Subiela \& Fernández, 2014), y reducir la latencia en el proceso de descubrimiento de nuevas rutas de los protocolos reactivos (Kaur, Sahni \& Bala, 2013).

Los protocolos híbridos realizan el proceso de descubrimiento de rutas basados en la filosofía de los protocolos reactivos, consideran, dentro de su métrica, factores como: puntos de referencia, localización y distancia entre nodos, para las actualizaciones de rutas (Rodríguez, 2005).

Entre los protocolos de ruteo híbrido se encuentran: Zone Routing Protocol [ZRP] (Jamwal, Kumar-Sharma \& Chauhan, 2015); Landmark Routing [LANMAR] (Gerla, Hong, \& Ma, 2003; Hong, Nguyen, Liu, \& Teng, 2014); Fisheye State Routing [FSR] (Gerla, Hong, \& Pei, 2002; Sarkar, Basavaraju, \& Puttamadappa, 2013); Sharp Hybrid Adaptive Routing Protocol [SHARP] (Ramasubramanian, Haas, \& Sirer, 2003); Zone-based Hierarchical Link State [ZHLS] (Wu, 2006); y Distributed Dynamic Routing [DDR] (Nikaein, Labiod, \& Bonnet, 2000).

\section{Aplicaciones de las MANET}

El uso de las tecnologías de la información y las comunicaciones ha sido una herramienta vital para romper barreras al acceso a la educación (Rico, 2013). Con la masificación de los dispositivos inteligentes y el avance de las tecnologías inalámbricas, las aplicaciones que usan MANETS se han incrementado. Estas aplicaciones son diversas y varían según su objetivo, tamaño, lugar de instalación, si están en constante movimiento o si son más estáticas, entre otras. Incluso se utilizan en control de tráfico, pues las Vehicular Ad Hoc Networks [VANET] son consideradas como una extensión del concepto MANET, pues en ellas cada vehículo es un nodo que forma parte de una red inalámbrica (Orozco, Llano \& Michoud, 2012; Orozco, Michoud \& Llano, 2013).

A continuación se presentan algunas de estas aplicaciones, con énfasis, como se anticipó en la Introducción, en educación.

\section{A. Educación}

Entre la variedad de aplicaciones enfocadas hacia la sociedad que pueden darse en las MANET, el área de la educación posee varios desarrollos que logran fortalecer sus actividades y obtener resultados que favorecen los procesos de enseñanza, aprendizaje y comunicación.

La aplicación de MANETs en ambientes educativos va, desde la posibilidad de ejecutar clases y generar salas de conferencias virtuales (Ghosekar, Katkar \& Ghorpade, 2010), hasta la expansión de señales inalámbricas en campus universitarios. En ellos, las redes WLAN ampliarían su rango de cobertura mediante la comunicación con una red Ad-Hoc que se expande y moviliza según el deseo del usuario, sin necesidad de instalar nuevos AP (Pérez, 2012), pues sólo basta con asegurar el enlace permanente entre la MANET y la WLAN, por medio de los nodos que van creando la red Ad-Hoc. Así, la red universitaria podrá au- ma, 2010); Location Aided Routing [LAR] (Ko \& Vaidya, 2000); and Link Quality Source Routing [LQSR] (Draves, Zill \& Padhey, 2008).

\section{Hybrid}

It is a combination of reactive and proactive routing protocols, was proposed in order to reduce the overloads of proactive protocols associated with the constant transmission of control messages to update routes (Subiela \& Fernández, 2014), and reduce the latency in the discovery process of new routes of reactive protocols (Kaur, Sahni \& Bala, 2013).

Hybrid protocols perform the process of route discovery based on the philosophy of reactive protocols, consider within their metric, factors such as reference points, location and distance between nodes, for route updates (Rodríguez, 2005). Among the hybrid routing protocols are: Zone Routing Protocol [ZRP] (Jamwal, Kumar-Sharma \& Chauhan, 2015); Landmark Routing [LANMAR] (Gerla, Hong, \& Ma, 2003; Hong, Nguyen, Liu, \& Teng, 2014); Fisheye State Routing [FSR] (Gerla, Hong, \& Pei, 2002; Sarkar, Basavaraju, \& Puttamadappa, 2013); Sharp Hybrid Adaptive Routing Protocol [SHARP] (Ramasubramanian, Haas, \& Sirer, 2003); Zone-based Hierarchical Link State [ZHLS] (Wu, 2006); Distributed Dynamic Routing [DDR] (Nikaein, Labiod, \& Bonnet, 2000).

\section{Applications of Manets}

The use of information and communication technologies has been a vital tool in breaking down barriers to access to education (Rico, 2013). With the widespread growth of smart devices and the advancement of wireless technologies, applications using MANETs have increased. These applications are diverse and vary according to their purpose, size, location, if they are constantly moving or if they are more static, among others. They are even used in traffic control, as the Vehicular Ad Hoc Networks [VANET] are considered as an extension of the MANET concept, because in them each vehicle is a node that is part of a wireless network (Orozco, Llano \& Michoud, 2012; Orozco, Michoud \& Llano, 2013). Below are some of these applications, with emphasis in education as anticipated in the Introduction.

\section{A. Education}

Among the variety of applications focused on society that can occur in the MANETs, the area of education has several developments that manage to strengthen their activities and obtain results that favor the processes of teaching, learning and communication. 
The application of MANETs in educational environments goes from the possibility of executing classes and generating virtual conference rooms (Ghosekar, Katkar \& Ghorpade, 2010), to the expansion of wireless signals on university campuses. In them, WLAN networks would expand their range of coverage through communication with an Ad-Hoc network that expands and mobilizes according to the desire of the user, without the need to install new APs (Pérez, 2012), since it is enough to ensure the permanent link between the MANET and the WLAN, through the nodes that are creating the Ad-Hoc network. Thus, the university network can increase its range considerably through the cooperation and massive connection of mobile devices.

On the other hand, the characteristics of the MANETs can be exploited, among them the low installation cost and the ease of deployment to generate networks in which information can be shared (Chalmeta, 2009), to improve the organization and cooperation of teachers and administrative in a rural school, for example, where there is no network infrastructure or Internet access to make use of instant messaging applications.

Similarly, through an intranet created by the Ad-Hoc network it is possible to deploy an offline platform where grades of students are stored and reported and be able to take control of the subject and the progress of the course, a platform that allows administration of the educational center.

It has also been proposed (Chaamwe \& Shumba, 2014) to use MANETs to implement networks that support e-learning for teaching in rural communities, in order to overcome the challenges of location, connectivity and access to schools, taking advantage of the fact that the use of mobile devices has increased considerably, even in rural areas.

The academic MANET aims to disseminate information of an educational nature so that people who live in areas within the coverage area of the Ad-Hoc network can access these contents and interact with them without having to leave their homes, where there are no built schools. Each area in which academic networks are created should have a telecentre where the contents and progress information of each of the students are stored.

A study conducted by Ghosh, Lasebae and Ever (2009) simulated the performance that a MANET would have when compared to a WLAN in an e-learning environment; their results conclude that the Ad-Hoc network can be used and remain stable, since it supports the load of e-learning environments in standard-size scenarios $500 \mathrm{~m}$ x 500m, obtaining optimal results in terms of delay. Using the AODV protocol, mentar su rango considerablemente mediante la cooperación y conexión masiva de dispositivos móviles.

Por otra parte, se pueden aprovechar las características de las MANET, entre ellas el bajo costo de instalación y la facilidad de despliegue, para generar redes en las que se pueda compartir información (Chalmeta, 2009), para mejorar la organización y cooperación de docentes y administrativos en una escuela rural, por ejemplo, donde no se posea infraestructura de red o acceso a Internet para hacer uso de aplicaciones de mensajería instantánea.

De igual forma, mediante una intranet creada por la red Ad-Hoc es posible el despliegue de una plataforma offline donde se almacenen y reporten las calificaciones del estudiantado y pueda llevarse el control de la asignatura y el progreso del curso, una plataforma que permita la administración del centro educativo.

Se ha propuesto además (Chaamwe \& Shumba, 2014) usar MANETs para implementar redes que soporten e-learning para la enseñanza en comunidades rurales, de tal manera que se superen los retos de ubicación, conectividad y acceso a escuelas, aprovechando que el uso de dispositivos móviles ha aumentado considerablemente, incluso en áreas rurales.

La MANET académica tiene como objetivo diseminar información de carácter educativo para que las personas que habiten en zonas dentro del área de cobertura de la red Ad-Hoc puedan acceder a éstos contenidos e interactuar con ellos sin necesidad de salir de sus casas, donde no existen centros educativos construidos. Cada zona en la que se generen redes académicas debería contar con un telecentro en donde se almacenan los contenidos y la información de progreso de cada uno de los estudiantes.

Un estudio realizado por Ghosh, Lasebae y Ever (2009) simuló el desempeño que tendría una MANET frente a una WLAN en un ambiente e-learning; sus resultados concluyen que la red Ad-Hoc puede usarse y mantenerse estable, puesto que soporta la carga de ambientes e-learning en escenarios de tamaño estándar 500m x 500m, obteniendo resultados óptimos en términos de retardo. Haciendo uso del protocolo AODV, y pruebas con escenarios de 5, 20 y 50 nodos generando peticiones, tiene un retardo de 0.1 segundos, inclusive cuando hay movilidad de nodos y cambios de trayectorias continuos.

En cuanto al promedio de desempeño (bits/seg), AODV arroja mejores resultados en redes grandes, por ello, manejando 50 y 100 nodos, el promedio de desempeño es de 2,000,000 (bits/seg) y 5,400,000 (bits/seg). En cuanto al tiempo de respuesta a una petición HTTP, una MANET con 20 nodos arroja resultados de 0.0 segundos, mientras que con 50 y 100 nodos, el promedio de respuesta es de 3.1 segundos, teniendo en cuenta el constante movimiento y cambio de topología que presenta la red.

Rabbi y Arefin (2006) hacen referencia al e-learning como método de aprendizaje para personas que habiten en áreas rurales, y toman como ejemplo regiones sur asiáti- 
cas, donde el acceso a la educación es muy complicado debido a la posición geográfica y a la falta de infraestructura.

Ésta alternativa es de gran provecho para países en vía de desarrollo, puesto que resulta eficiente en relación costo-beneficio debido a que es muy complicado llevar la educación de la ciudad a zonas con difícil acceso, pues el abastecimiento de kioskos con equipos de cómputo para el acceso a material interactivo y educativo de todos los niveles resulta más asequible que la construcción de escuelas y la contratación de maestros. Se propone que cada zona rural tenga al menos un kiosco donde, además de guardar el contenido interactivo, se almacene la información relativa a los habitantes - edad, gustos, condición médica, ocupación actual, entre otros-.

Mediante el uso de un MAP (Mobile Access Point), un vehículo que usa Low Cost WiFi con un punto de acceso montado, que al moverse alrededor de los kioskos crea una red Ad-Hoc, permite la descarga y alimentación de datos entre el kiosco y el MAP; se recomienda el uso de las especificaciones $802.11 \mathrm{~b} / \mathrm{g}$ que operan en un rango de frecuencia de $2.4 \mathrm{GHz}$, ya que son los que ofrecen más cobertura y alcanzan velocidades de hasta $11 \mathrm{Mb} / \mathrm{s}$. Luego de descargada y almacenada la información en el MAP, éste viaja a la ciudad y crea otra red Ad-Hoc transmitiendo la información por transceptores de radio frecuencia al Data Processing Center [DPG]. La información se guarda y se procesa, para luego añadir nuevo contenido educativo que será enviado a los kioskos mediante el MAP.

Grew y Pagani (2005) proponen sacar provecho de las MANET para formar grupos exclusivos de estudio en un campus universitario o fuera de él. Las MANET se formarán bajo demanda con un fin común, de manera colaborativa y con un tiempo de vida reducido. Por ejemplo, al iniciar una lección de una clase específica se crea una MANET para compartir información relacionada entre estudiantes y profesores que permita además, solicitar recursos de manera efectiva a la red del campus, que sólo será accesible para los interesados si la MANET es conformada al interior de la academia.

La creación de foros de discusión, publicación de apuntes, formulación y resolución de preguntas -al docente o a los demás integrantes-, son algunos de los usos que se pueden dar a la infinidad de aulas virtuales de diversos temas que pueden ser creadas.

Es importante resaltar que no siempre se requiere estar presente en el campus o contar con la supervisión de un docente, las aulas virtuales se pueden conformar con fines de colaboración, como en grupos de estudio o en prácticas profesionales.

En las áreas de la salud o ingeniería, que desarrollan sus clases en escenarios alejados del campus y del acceso a Internet, aspectos cruciales como el registro de hallazgos, la formación de grupos de discusión o el compartir información, pueden ser apoyados por las MANET educativas.

Planteado de forma similar a lo expuesto en Grew y Pa- and tests with scenarios of 5, 20 and 50 nodes generating requests, it has a delay of 0.1 seconds, even when there is mobility of nodes and changes of continuous trajectories. Regarding average performance (bits/sec), AODV delivers better results in large networks, therefore, managing 50 and 100 nodes, the performance average is 2,000,000 (bits/sec) and 5,400,000 (bits/sec). Regarding the response time to an HTTP request, a MANET with 20 nodes gives results of 0.0 seconds, while with 50 and 100 nodes, the average response is 3.1 seconds, taking into account the constant movement and topology change that presents the network.

Rabbi and Arefin (2006) make reference to e-learning as a method of learning for people who live in rural areas, and take as an example South Asian regions, where access to education is very complicated due to the geographical position and the lack of infrastructure.

This alternative is very useful for developing countries, since it is efficient in benefit-cost ratio because it is very difficult to take the education of the city to areas with difficult access, as the supply of kiosks with computer equipment for access to interactive and educational material at all levels is more affordable than building schools and hiring teachers. It is proposed that each rural area have at least one kiosk where, in addition to saving the interactive content, to make possible the store of information relating to the inhabitants -age, preferences, medical condition, current occupation, among others-.

Through the use of a MAP (Mobile Access Point), a vehicle that uses Low Cost WiFi with an access point mounted, while moving around the kiosks creates an Ad-Hoc network, allows the download and feeding of data between the kiosk and the MAP; the use of $802.11 \mathrm{~b} / \mathrm{g}$ specifications that operate in a frequency range of $2.4 \mathrm{GHz}$ is recommended, since they offer the most coverage and reach speeds of up to $11 \mathrm{Mb} / \mathrm{s}$. After the information is downloaded and stored in the MAP, it travels to the city and creates another Ad-Hoc network transmitting the information by radio frequency transceivers to the Data Processing Center [DPG]. The information is saved and processed to then add new educational content that will be sent to the kiosks through the MAP.

Grew and Pagani (2005) propose to take advantage of the MANETs to form exclusive study groups on a university campus or outside of it. The MANET will be formed on demand with a common purpose, in a collaborative way and with a reduced life time. For example, when initiating a lesson of a specific class, a MANET is created to share related information between students and teachers,which also allows to 
request resources in an effective way to the campus network, which will only be accessible for those interested if the MANET is formed inside the academy.

The creation of forums for discussion, publication of notes, formulation and resolution of questions - to the teacher or to the other members-, are some of the uses that can be given to the infinity of virtual classrooms of diverse topics that can be created.

It is important to emphasize that it is not always necessary to be present on campus or to have the supervision of a teacher, virtual classrooms can be set up for collaborative purposes, such as study groups or professional practices.

In the areas of health or engineering that develop their classes in scenarios far from the campus and access to the Internet, crucial aspects such as recording findings, forming discussion groups or sharing information can be supported by educational MANETs.

Raised in a similar way to Grew and Pagani (2005), a very useful application that can be given to Ad-Hoc networks in education is the one presented by Köning-Ries and Klein (2002), who propose the creation of a network between terminals to share documents, images, articles, slides and even applications, and in this way facilitate the acquisition of resources for students and teachers, without the need to connect to the Internet, since the information provided will be used by the terminals involved in the network. As some student or teacher needs educational services, these are created or requested from other users, making this type of networks have the characteristic of being multipurpose.

An additional characteristic is the transparency of the processes, because the search and use of the elements is transparent to the user, which means that the user only has to worry about learning.

It is important to denote that it is also possible to make use of machines in the Ad-Hoc network as a bridge for connection with other fixed networks, for example that of a university campus, and thus be able to connect to the Internet.

García, Tapia, Rodríguez and Corchado (2010) highlight how important it is for the teacher to know the interaction between students in a formal and informal way, to have indexes about the most consulted topics, which cause more difficulty and those that have already been successfully learned, for this purpose, support in the MANETs is important. Teachers are considered as master nodes or super nodes and have the possibility to collect the information generated in the MANETs, to analyze or process it as desired and thus be gani (2005), un uso muy útil que se le puede dar a las redes Ad- Hoc en el ámbito educativo es el expuesto por Köning-Ries y Klein (2002), quienes proponen la creación de una red entre terminales para compartir documentos, imágenes, artículos, diapositivas y hasta aplicaciones, y de esta forma facilitar la adquisición de recursos a estudiantes y docentes, sin la necesidad de conectarse a Internet, puesto que se hará uso de la información suministrada por los terminales involucrados en la red. A medida que algún estudiante o docente va necesitando servicios educativos, éstos se van creando o solicitando a otros usuarios, haciendo que este tipo de redes tengan la característica de ser multipropósito.

Una característica adicional, es la transparencia de los procesos, debido a que la búsqueda y uso de los elementos es transparente al usuario, con lo que se logra que éste sólo deba preocuparse por el aprendizaje.

Es importante denotar que también se puede hacer uso de máquinas en la red Ad-Hoc como puente para la conexión con otras redes fijas, por ejemplo la de un campus universitario, y así poderse conectar a Internet.

García, Tapia, Rodríguez y Corchado (2010) destacan lo imperioso que es para el maestro conocer la interacción entre los estudiantes de manera formal e informal, para tener índices acerca de los temas más consultados, los que causan más dificultad y aquellos que ya han sido aprendidos con éxito, para este objetivo es importante el apoyo en las MANET. Los docentes son considerados como nodos maestros o súper nodos y tienen la posibilidad de recopilar la información generada en las MANET, para analizarla o procesarla como se desee y así poder obtener conclusiones y tomar medidas con respecto de lo sucedido en el aprendizaje de los estudiantes.

Saatz y Kienle (2013) adicionan a las MANET el uso de tags electrónicos para hacer del aprendizaje colaborativo una actividad más lúdica e interactiva. Su uso se destinaría como una forma de evaluación para los docentes o como un método de preparación para exámenes.

Luego de conformada la MANET por conexión Bluetooth entre los interesados, se empezará a hacer uso de las smart tag que con anterioridad fueron cargadas con una pregunta y una o más opciones de respuesta asociada. Mediante el uso de una aplicación compartida por todos los interesados se asignan los roles de quién pregunta y quién responde, para lanzar preguntas completas o parciales, esperar respuestas y comentar los resultados obtenidos, apoyados en el uso de web services y redes Ad-Hoc en dispositivos móviles.

Gregory (2015) establece que es un reto para las instituciones educativas hacer uso del teléfono celular como herramienta para el aprendizaje y apoyo en la educación de los jóvenes, y no como un distractor potencial poco aceptado en las propias aulas.

Teniendo en cuenta lo mencionado, se plantea el uso del protocolo Real Time-Dynamic Source Routing [RT- 
DSR], desarrollado con base al protocolo DSR con la adición de nuevas características.

Estudios realizados en áreas rurales de Nigeria establecieron que el protocolo resulta eficiente para prestar servicios de vídeo en una red Ad-Hoc, y logra transmitir, exitosamente, el 80\% del mismo. Este avance ayuda en gran medida al establecimiento de ambientes e-learning donde sea vital el uso de transmisión en tiempo real para el aprendizaje del alumno.

Son varias las aplicaciones atribuidas a las MANET enfocadas en la educación; es importante que ellas sean atendidas por la sociedad para así disminuir el impacto que existe en comunidades con pocos recursos, alejadas de las ciudades, sin infraestructura tecnológica, sin colegios, donde el acceso a la información es muy difícil, pero donde igual se necesita la educación como una herramienta de progreso.

Las tecnologías móviles, explica Brown (2005) “tienen el poder de hacer que el aprendizaje sea aún más accesible y disponible de lo que se está acostumbrado en los ambientes de aprendizaje basados en la web existente".

\section{B. Otros escenarios}

\section{Escenarios de emergencia}

En eventos como catástrofes naturales, tales como terremotos, inundaciones, huracanes o tsunamis, donde generalmente la infraestructura de comunicación se ve afectada en gran medida, es posible, gracias a las propiedades de las MANET, instalar una red de comunicación (Aarti \& Tyagi, 2013).

\section{Operaciones de búsqueda}

Utilizando MANET es posible la creación de áreas de cobertura de comunicación, para así informar de los avances en el hallazgo del objetivo a encontrar.

\section{Misional}

Debido al rápido despliegue y al tiempo de vida variable de las MANET, éstas pueden ser usadas para compartir información en un auditorio y permitir que dispositivos del hogar logren comunicarse (Bang \& Ramteke, 2013) o transferir información en un centro comercial, conferencia, reunión de negocios, y demás eventos en los que sea necesaria la comunicación.

\section{Redes militares}

Generalmente los campos de batalla, los campamentos, los vehículos (Orozco et al., 2012; 2013) militares y los mismos soldados, poseen dispositivos móviles de los cuales se puede hacer uso para adecuar una red de comunicación de este tipo (Kaur \& Sharma, 2013).

\section{Sensores}

Sensores, que notifican al usuario una acción, pueden ser instalados en los hogares para detectores de humo, detectores de movimiento y en los electrodomésticos. Las Body Area Network [BAN] (Betancur, 2011; Kaur \& Sharma, 2013) entran en esta clasificación, pues tienen como objetivo informar al usuario sobre su presión arterial, el rit- able to obtain conclusions and take action regarding what happened in the learning of students.

Saatz and Kienle (2013) add electronic tags to MANET to do collaborative learning a more playful and interactive activity. Its application would be used as a form of evaluation for teachers or as a method of preparation for exams.

After conforming the MANET by Bluetooth connection between the interested parties, it will begin to make use of the smart tags that were previously loaded with a question and one or more associated response options. Through the use of an application shared by all interested parties, the roles of who asks and who answers are assigned, to launch complete or partial questions, wait for answers and comment on the results obtained, supported by the use of web services and Ad-Hoc networks in mobile devices.

Gregory (2015) states that it is a challenge for educational institutions to use the cell phone as a tool for learning and support in the education of young people, and not as a potential distractor that is little accepted in the classrooms themselves.

Taking into account the aforementioned, the use of the Real Time-Dynamic Source Routing protocol [RT-DSR], developed based on the DSR protocol with the addition of new characteristics is proposed. Studies conducted in rural areas of Nigeria established that the protocol is efficient to provide video services in an Ad-Hoc network, and successfully transmits $80 \%$ of it. This advance greatly helps the establishment of e-learning environments where the use of real-time transmission for student learning is vital.

There are several applications attributed to MANETs focused on education; it is important that they are taken care of by society in order to reduce the impact that exists in communities with few resources, far from the cities, without technological infrastructure, without schools, where access to information is very difficult, but where the education is needed as a tool of progress. Mobile technologies, Brown (2005) explains, "have the power to make learning even more accessible and available than is customary in existing web-based learning environments."

\section{Other scenarios}

\section{Emergency scenarios}

In events such as natural catastrophes, such as earthquakes, floods, hurricanes or tsunamis, where the communication infrastructure is generally affected to a large extent, it is possible, thanks to the properties of the MANETs, to install a communication network (Aarti \& Tyagi, 2013). 


\section{Search operations}

Using MANET it is possible to create communication coverage areas, in order to report on the progress made in finding the objective to be achieve.

\section{Missionary}

Due to the rapid deployment and variable life time of the MANETs, these can be used to share information in an auditorium and allow household devices to communicate (Bang \& Ramteke, 2013) or transfer information in a shopping center, conference, meeting of business, and other events in which communication is necessary.

\section{Military networks}

Generally battlefields, camps, military vehicles (Orozco et al., 2012; 2013) and soldiers themselves, have mobile devices which can be used to adapt a communication network of this type (Kaur \& Sharma, 2013).

\section{Sensors}

Sensors, which notify the user of an action, can be installed in homes for smoke detectors, motion detectors and electrical appliances. The Body Area Network [BAN] (Betancur, 2011; Kaur \& Sharma, 2013) fall into this classification, as they aim to inform the users about their blood pressure, heart rate, glucose level and calories burned or acquired; in addition, if necessary, they can communicate with a health center or call an ambulance.

\section{Collaboration network}

Sometimes it is necessary to create a network for the transfer of work information that has a coverage inside and outside of an office or company (Aarti \& Tyagi, 2013) and allow employees mobility and access to data.

\section{Conclusions}

It is recommended to take advantage of the widespread growth of mobile devices in society to increase the usability of the MANET networks, this technology has great potential, which must be used, to a large extent, by the communities, to generate cooperative networks that allow the diffusion of information.

The applicability of MANET networks in the educational field allows to distribute teaching contents in vulnerable communities that do not have schools or the adequate network infrastructure to use interactive content, and thus helps in the educational process of the student body. In the same way, they can be used to share information and generate study groups, with or without the participation of teachers, to facilitate and strengthen learning with tools such as forums, dis- mo cardíaco, el nivel de glucosa y las calorías quemadas o adquiridas; además, en caso de ser necesario, permiten comunicarse con un centro de salud o llamar a una ambulancia.

\section{Red de colaboración}

En ocasiones es necesaria crear una red para la transferencia de información de trabajo que posea una cobertura dentro y fuera de una oficina o empresa (Aarti \& Tyagi, 2013) y permita a los empleados movilidad y acceso a los datos.

\section{Conclusiones}

Se puede aprovechar la masificación de los dispositivos móviles en la sociedad para aumentar la usabilidad de las redes MANET, ésta tecnología tiene gran potencial, el mismo que debe ser aprovechado, en gran medida, por las comunidades, para generar redes cooperativas que permitan la difusión de información.

La aplicabilidad de redes MANET en el campo educativo permite distribuir contenidos de enseñanza en comunidades vulnerables que no poseen escuelas o la infraestructura de red adecuada para usar contenido interactivo, y ayuda así en el proceso educativo del estudiantado. De la misma forma, pueden ser usadas para compartir información y generar grupos de estudio, con o sin la participación de docentes, que faciliten y fortalezcan el aprendizaje con herramientas como foros, grupos de discusión, aulas virtuales, solicitud de recursos y búsqueda de contenido.

El amplio desarrollo de las redes MANET -y de los protocolos que las soportan- brinda al usuario una solución económica, auto-organizada, auto-mantenible y móvil, que soporta un gran potencial de ejecución de aplicaciones y una muy buena alternativa cuando la implementación de redes WLAN genera inconvenientes o cuando es necesario ampliación el radio de cobertura de la misma.SRT 
cussion groups, virtual classrooms, requesting resources and searching for content.

The extensive development of the MANET networks - and the protocols that support them- provides the user with an economic, self-organized, self-maintainable and mobile solution that supports a great potential for the execution of applications and a very good alternative when the implementation of WLAN networks generates inconveniences or when it is necessary to extend the coverage radius of the same.ST 


\section{References / Referencias}

Adafruit FONA 808 - Mini Cellular GSM + GPS Breakout (2016). Retrieved from: https://www.adafruit.com/product/2542

Aarti, \& Tyagi, S. (2013). Study of Manet: Characteristics, challenges, application and security attacks. International Journal of Advanced Research in Computer Science and Software Engineering, 3(5), 252-257.

Aguilera, U. (2013). Nuevos protocolos para el descubrimiento y la composición automática de servicios en redes móviles ad hoc [Ph.D .thesis]. Universidad de Deusto: Bilbao, España.

Alonso, G. \& Rivera, J. (2007). Extension to MAC 802.11 for performance improvement in MANET [master thesis]. Karlstad University: Sweden.

Bang, A., \& Ramteke, P. (2013). MANET: History, challenges and applications. International Journal of Application or Innovation in Engineering \& Management, 2, 251.

Basagni, S., Chlamtac, I., Syrotiuk, V. R., \& Woodward, B. A. (1998). A distance routing effect algorithm for mobility (DREAM). In Proceedings of the 4th annual ACM/IEEE international conference on Mobile computing and networking, (pp. 76-84). New York, NY: ACM

Bertolín, A. (2012). Análisis de riesgos y contramedidas en redes MANET. Revista Española de Electrónica, 687, 62.

Betancur, L. (2011). Body Area Network: a perspective to the future, from research. Sistemas \& Telemática, 9(16), 11-30. doi: 10.18046/syt.v9i16.1027.

Bokotey, D., Mason, A., \& Morrow, R. (2003). CCIE practical studies. Indianapolis, IN: Cisco.

Chaamwe, N. \& Shumba, L. (2014). e-Learning using wireless ad-hoc networks to support teaching and learning in rural Zambia. Proceedings and Report of the 7Th Ubuntunet Alliance Annual Conference, 1(1), 51-58.

Chalmeta, J. (2009). Estudio y análisis de prestaciones de redes móviles Ad Hoc mediante simulaciones NS-2 para validar modelos analíticos [Ph.D. thesis]. Escuela Técnica Superior de Ingeniería de Telecomunicaciones de Barcelona: España.

Chang, Z., Gaydadjiev, G., \& Vassiliadis, S. (2005). Routing protocols for mobile ad-hoc networks: current development and evaluation. In Annual Workshop on Circuits, Systems and Signal Processing (pp. 489-494).

Cho, K. (2005). Technologies for advanced heterogeneous networks. Berlin, Germany: Springer.

Clausen, T. \& Jacquet, P. (2003, October). Optimized link state routing protocol (OLSR). IETF. Retrieved from: https://www. ietf.org/rfc/rfc3626.txt

Díaz, J. F., Marrone, L. A., Barbieri, A., \& Robles, M. (2010). Ruteo en redes ad-hoc. In: XII Workshop de Investigadores en Ciencias de la Computación, (pp. 18-21). RedUNCl

Draves Jr, R. P., Zill, B. D., \& Padhye, J. D. (2008). U.S. Patent No. 7,376,122. Washington, DC: U.S. Patent and Trademark Office.

Echaiz, J., Davicino, P., \& Ardenghi, J. (2012). Seguridad en MANETs. In: XIV Workshop de Investigadores en Ciencias de la Computación, (pp. 758-762). Recuperado de: http://sedici.unlp.edu.ar/bitstream/handle/10915/19322/Documento_completo.pdf?sequence $=1)$

Frikha, M. (2011). Ad hoc networks routing, QoS and optimization. London, UK: ISTE.

Frodigh, M., Johansson, P., \& Larsson, P. (2000). Formación de redes inalámbricas ad hoc: el arte de la formación de redes sin red. Ericsson Review, 4, 252.

García, B. (2009). Gabinetes de comunicación on line. Sevilla, España: Comunicación Social.

García, Ó., Tapia, D. I., Rodríguez, S., \& Corchado, J. M. (2010, June). Ambient intelligence application scenario for collaborative e-learning. In International Conference on Industrial, Engineering and Other Applications of Applied Intelligent Systems (pp. 407-416). Berlin, Germany: Springer.

Gerla, M., Hong, X., \& Ma, L. (2003, November 22). Landmark routing protocol (LANMAR) for large scale ad hoc networks. Retrieved from: https://tools. ietf.org/html/draft-ietf-manet-lanmar-05

Gerla, M., Hong, X., \& Pei, G. (2002, June 17). Fisheye State Routing protocol (FSR) for ad hoc networks. Retrieved from: https://tools. ietf.org/html/draft-ietf-manet-fsr-03

Ghosekar, P., Katkar, G., \& Ghorpade, P. (2010). Mobile ad hoc networking: imperatives and challenges. IJCA, Special Issue on MANETS, 3, 153-158.

Ghosh, A., Lasebae, A., \& Ever, E. (2009). Performance evaluation of wireless IEEE 802.11 (b) used for ad-hoc networks in an e-learning classroom network. Kaspersky International Cybercrime Conference, 3(1), 49-55.

González, C. (2012). Estudio de los protocolos de routing y el impacto de la movilidad en MANETs [thesis]. Universitat Politécnica de Catalunya: Barcelona, España.

Gregory, O. (2015). Enhanceing access to education through mobile learning. International Journal of Emerging Technology \& Research, 2(5), 1-4.

Grew, P., \& Pagani, E. (2005, June). Towards a wireless architecture for mobile ubiquitous e-Learning. In Proc. Intl. Workshop on Learning Communities in the Era of Ubiquitous Computing (pp. 20-29).

Gupta, A., Sadawarti, H., \& Verma, A. (2010). Performance analysis of AODV, DSR \& TORA routing protocols. IACSIT International Journal of Engineering and Technology, 2(2), 226.

Helen, D. \& Arivazhagan, D. (2014). Applications, advantages and challenges of ad hoc networks. Journal of Academia and Industrial Research, 2(8), 453-456.

Hong, X., Nguyen, N., Liu, S., \& Teng, Y. (2014). Dynamic group support in LANMAR routing ad hoc networks. In: 4th International Workshop on Mobile and Wireless Communications Network. IEEE. doi:10.1109/MWCN.2002.1045742 
Ishibashi, B. \& Boutaba, R. (2005). Topology and mobility considerations in mobile ad hoc networks. Ad Hoc Networks, 3(6), 762-776.

Jacquet, P., Muhlethaler, P., Clausen, T., Laouiti, A., Qayyum, A., \& Viennot, L. (2001). Optimized link state routing protocol for ad hoc networks. In Multi Topic Conference, 2001. IEEE INMIC 2001. Technology for the 21st Century. Proceedings. (pp. 62-68). IEEE.

Jamwal, D., Kumar-Sharma, K., \& Chauhan, S. (2015). Zone routing protocol. International Journal of Recent Research Aspects, 1, 16-20.

Johnson, D., Hu, Y., \& Maltz, D. (2007, February). The Dynamic Source Routing protocol (DSR) for mobile ad hoc networks for IPV4. Retrieved from: https://www.ietf.org/rfc/rfc4728.txt

Kaur, H., Sahni, V., \& Bala, M. (2013). A survey of reactive, proactive and hybrid routing protocols in MANET: A review. International Journal of Computer Science and Information Technologies, 4(3), 498-500.

Kaur, S., \& Sharma, C. (2013). An overview of mobile ad hoc network: Application, challenges and comparison of routing protocols. IOSR Journal of Computer Engineering, 11(5), 7-11.

Ko, Y. \& Vaidya, N. (2000). Location-Aided Routing (LAR) in mobile ad hoc networks. Wireless Networks, 6, 307-321.

Köning -Ries, B. \& Klein, M. (2002). Information services to support e-learning in ad-hoc networks. In: First International Workshop on Wireless Information Systems (WIS2002). Retrieved from: http://fusion.cs.uni-jena.de/fusion/wp-content/uploads/2015/05/wis.pdf

Kumar, M. A., Selvarani, R., \& Kumar, T. (Eds.). (2013). Proceedings of International Conference on Advances in Computing. New Delhi, India: Springer.

Lara, R., Olmedo, G., \& Rodríguez, L. (S.F). Evaluación de protocolos de enrutamiento usados en las redes móviles Ad hoc (MANET), utilizando el software Network Simulator NS-2. Recuperado de: https://www.academia.edu/4734203/Evaluaci\%C3\%B3n_de_Protocolos_de_Enrutamiento_usados_en_las_Redes_M\%C3\%B3viles_AdHoc_MANET_utilizando_el_software Network_Simulator_ns-2

Latiff, L. A., \& Fisal, N. (2003). Routing protocols in wireless mobile ad hoc network-a review. In Communications, 2003. APCC 2003. The 9th Asia-Pacific Conference on (Vol. 2, pp. 600-604). IEEE.

López, J., Barceló, J. M., \& García-Vidal, J. (2005). Ventajas de usar subredes en una red ad-hoc con nodos móviles. In: Proc. of XV Jornadas Telecom i+ d. Madrid, España: ETSIT.

Murazzo, M., Rodríguez, N., \& Martínez, M. (2008). Evaluación del retardo de los protocolos de ruteo reactivos para redes MANET. Revista de Ingeniería Electrónica, Automática y Comunicaciones, 29(1), 28-35.

Neumann, A., Aichele, C., Lindner, M., \& Wunderlich, S. (2008, March 30). Better approach to mobile ad-hoc networking (BATMAN). Retrieved from: https://tools.ietf.org/html/draft-openmesh-b-a-t-m-a-n-00

Nielsen. (2014). The digital customer. (2014). Recuperado de: http://www.nielsen.com/content/dam/corporate/us/en/reportsdownloads/2014\%20Reports/the-digital-consumer-report-feb-2014.pdf

Nikaein, N., Labiod, H., \& Bonnet, C. (2000, November). DDR: distributed dynamic routing algorithm for mobile ad hoc networks. In Proceedings of the 1st ACM international symposium on Mobile ad hoc networking \& computing (pp. 19-27). IEEE.

Orozco, A., Llano, G., \& Michoud, R. (2012). Redes vehiculares Ad-hoc: aplicaciones basadas en simulación. Ingenium, 6(12), 11-22. doi:http://dx.doi.org/10.21774/ing.v6i12.51

Orozco, A., Michoud, R., \& Llano, G. (2013). Routing protocols simulation for efficiency applications in vehicular environments. Sistemas \& Telemática, 11(27), 27-42. doi:10.18046/syt.v11i27.1693

Park, V., \& Corson, S. (2001, July). Temporally-Ordered Routing Algorithm (TORA). Version 1. Functional specification. letf.org. Retrieved from: http://www.ietf.org/proceedings/53/I-D/draft-ietf-manet-tora-spec-04.txt

Parker, J. (2011). Observation techniques for detecting malicious behavior in ad hoc networks [thesis]. University of Maryland: Baltimore, MD

Pérez, J. (2012). Protocolos de encaminamiento IP en dispositivos móviles para crear redes MANETS [thesis]. Universidad de Granada: España.

Perkins, C. E. \& Bhagwat, P. (1994, Octubre). Highly dynamic destination-sequenced distance-vector routing (DSDV) for mobile computers. In ACM SIGCOMM computer communication review, (pp. 234-244). New York, NY: ACM.

Perkins, C., Belding-Royer, E., \& Das, S. (2003a, July). RFC 3561 - Ad hoc On-Demand Distance Vector (AODV) routing. Retrieved from: https://tools.ietf.org/html/rfc3561

Perkins, C., Belding-Royer, E., \& Das S. (2003b, July). Ad-hoc on-demand distance vector routing. Retrieved from: https:// www.rfc-editor.org/rfc/rfc3561.txt

Rabbi, F. \& Arefin, A. (2006). E-learning using wireless ad-hoc network to support people of rural areas. International Conference on Communication Technology, 1(1), 1-4.

Ramasubramanian, V., Haas, Z. J., \& Sirer, E. G. (2003, June). SHARP: A hybrid adaptive routing protocol for mobile ad hoc networks. In: Proceedings of the 4th ACM international symposium on Mobile ad hoc networking \& computing (pp. 303314). ACM.

Rey, L. C., Quiñones, T. O. L., \& García, W. B. (2014a). Protocolos de enrutamiento aplicables a redes MANET. Revista Telem@ tica, 13(3), 59-74.

Rey, L. C., Quiñones, T. O. L., \& García, W. B. (2014b). Selección del protocolo de enrutamiento para la implementación de una MANET. In: Proceedings of VIII Congreso Internacional de Telecomunicaciones y Telemática (CITTEL 2014) (pp. 12351245). 
Rico, D. (2013). Propuesta de un modelo de evaluación de los procesos de enseñanza-aprendizaje en entornos e-learning. Ingenium, 7(16), 25-38. doi:10.21774/ing.v7i16.265

Rocabado, S., Arias, D., Díaz, J., \& Moreno, R. (2013). Caso de estudio de comunicaciones seguras sobre redes móviles Ad Hoc. Recuperado de: https://www.researchgate.net/profile/Sergio Rocabado/publication/281850130_Caso de estudio_de_comunicaciones_seguras_sobre_redes_moviles_ad_hoc/links/55fb3b5808aeba1d9f3a106f.pdf

Rodríguez, L. (2005). Protocolo de ruteo híbrido para redes móviles Ad Hoc - PRHIMANET- [thesis]. Instituto Politécnico Nacional: Ciudad de México.

Saatz, I. \& Kienle, A. (2013). Mobile support for ad hoc learning communities. Workshop on Collaborative Technologies for Working and Learning, 1(1), 1-5.

Sarkar, S., Basavaraju, T., \& Puttamadappa, C. (2013). Ad hoc mobile wireless networks. Boca Raton,. FL: CRC.

Shelby, Z. \& Bormann, C. (2009). 6LoWPAN. Chichester, UK: Wiley.

Singh, K. \& Awasthi, A. (2013). Quality, reliability, security and robustness in heterogeneous networks. Berlin, Germany: Springer.

Stojmenovic, I. \& Lin, X. (2001). Power-aware localized routing in wireless networks. IEEE Transactions on Parallel and Distributed Systems, 12(11), 1122-1126.

Subiela, R. \& León, A. (2014). Simulación de protocolos de encaminamiento en redes móviles ad hoc con NS2. Retrieved from: http://personales.upv.es/aleon/pubs/ursi05.pdf

The Computer Technology Documentation Project. (2013). Source routing. Retrieved from: http://www.comptechdoc.org/independent/networking/terms/source-routing.html

Wu, J. (2006). Handbook on theoretical and algorithmic aspect of sensor, ad hoc wireless, and peer-to-peer networks. Boca Raton, FL: Auerbach /CRC.

Yadav, M. \& Uparosiya, N. (2014). Survey on MANET: Routing protocols, advantages, problems and security. International Journal of Innovative Computer Science \& Engineering, 1, 12-17.

Zigbee Alliance (2016). Open standards development. Retrieved from: http://www.zigbee.org/zigbeealliance/developing-standards/ 


\section{CURRICULUM VITAE}

María Alejandra Bernal López Telematics Engineer from the Universidad Distrital Francisco José de Caldas (Bogotá, Colombia) and Technologist is Data Systematization / Ingeniera Telemática de la Universidad Distrital Francisco José de Caldas (Bogotá, Colombia) y Tecnóloga en Sistematización de Datos.

Wilfer Sneyder Cortés Urrea Telematics Engineer from the Universidad Distrital Francisco José de Caldas (Bogotá, Colombia) and Technologist is Data Systematization / Ingeniero Telemático de la Universidad Distrital Francisco José de Caldas (Bogotá, Colombia) y Tecnólogo en Sistematización de Datos.

Miguel Ángel Leguizamón Páez Systems Engineer and Specialist in Informatics Systems Management from the Universidad de Boyacá (Colombia); He obtained a Master's degree in Information and Communications Sciences from the Universidad Distrital Francisco José de Caldas (Bogotá, Colombia), where he is presently professor at the Engineering Faculty / Ingeniero de Sistemas y Especialista en Gerencia de Sistemas Informáticos de la Universidad de Boyacá (Colombia); Máster en Ciencias de la Información y las Comunicaciones de la Universidad Distrital Francisco José de Caldas (Bogotá, Colombia), institución donde actualmente se desempeña como docente de la Facultad de Ingeniería. 